JMKSP (Jurnal Manajemen, Kepemimpinan, dan Supervisi Pendidikan)

Volume 6 Issue 2 (2021) Page 181-199

ISSN 2614-8021 (Online) 2548-7094 (Print)

\title{
The Contribution of Sangga Buana Community as a Learning Media of Civic Engagement Education Based on Ecological and Cultural
}

\author{
Eko Digdoyo ${ }^{1}$, Endang Danial ${ }^{2}$, Prayoga Bestari ${ }^{3}$, Rudy Gunawan ${ }^{4}$ \\ ${ }_{1,2,3}$ Universitas Pendidikan Indonesia, ${ }^{4}$ Universitas Muhammadiyah Prof. Dr. \\ Hamka Jakarta \\ Corresponding Author E-mail: ekodigdoyo77@yahoo.co.id
}

Received 22 April 2021; Revised 23 April 2021; Accepted 30 April 2021

\begin{abstract}
The aim of this article was developing learning material for Civic Engagement Education based on ecological and cultural wisdom. The object of the study was the Central Sangga Buana Karang farmer community. The theoretical approaches that are considered relevant are those that are anthropological, ecological, and biological in nature. The results of the study show that Jakarta, apart from being the center of the economy, politics-bureaucracy, education and culture, as well as the center for the development of science and technology, is generally also the center of urbanization from various motives and backgrounds (migration). As a result of migration and population development that is not in line with geographical conditions, environmental and demographic management are to be separate problems that cannot be resolved by DKI Jakarta Government. For instance, the rampant illegal settlements have caused damage and pollution to the environment. However, in the South Jakarta area, especially in the Pesanggrahan Karang Tengah River watershed, there was a protected urban forest area that has been successfully managed by Sangga Buana volunteers using an ecological and cultural wisdom approach. This community efforts can be developed as one of the study materials for Community Citizenship Education.
\end{abstract}

Keyword: Sangga Buana Community, Civic Education, Ecology Wisdom 


\section{Introduction}

The people have an imagination and hope of becoming the center of civilization along with a better environment. As noted by Tidball, \& Krasny, (2010), Krasny et al., (2013), (2015), the role of ecology for society is actually very important because a good environment will automatically shape the attitudes and behavior of good citizens. However, these expectations often face various obstacles because the people often encounter the dynamics of development policies, as well as the backgrounds of the urbanizing population (Dudley \& Gitelson, 2003; Lukito, 2018). These various challenges and problems include the behavior of the people who lack awareness, especially in maintaining the harmony of life between humans and their environment (Walsh, et al., 2013; Bearss, 2015). For this reason, Dunn (2004) explained that in an effort to solve the problems related to the ecological awareness of urban communities, it is not enough to be done only by certain parties. Thus, it is necessary to involve related parties such as; government, educational institutions, business world, and social groups that are concerned about and have concern for ecology. As stated by Fauzi \& Bestari (2019), building public awareness can also be done through a political-policy education approach.

With regard to the object of this study, it is expected that Jakarta improve the quality of life of its people from the perspective of ecological awareness. Because, in reality there are many cases where a community that lack awareness of their environment apparent. Keraf (2002) \& Gea (2005) in their book "Relationships with the Natural World, Science and Technology, and Work" emphasize that in the midst of population density, urban people still need public spaces, which is a combination of natural, building, and social environments as a facility for social interaction. The goal is to create an environment that is safe, comfortable, orderly, and serene.

However, until now Jakarta is still dealing with the dynamics of population problems, as well as the management of ecological use that has not been going well. In addition, referring to the statistical data on the development of the population of DKI Jakarta in 2018 (Putri, et al., 2018; Sidabutar, T., \& Srimariana, 2020; Mandasari, et al., 2021), one of the reasons is the increasing 
development of the population from year to year. As an overview, the data on the development of the population of Jakarta from 2015-2018 is illustrated below.

Figure 1.DKI Jakarta Population Development by Year of Year 2015-2018

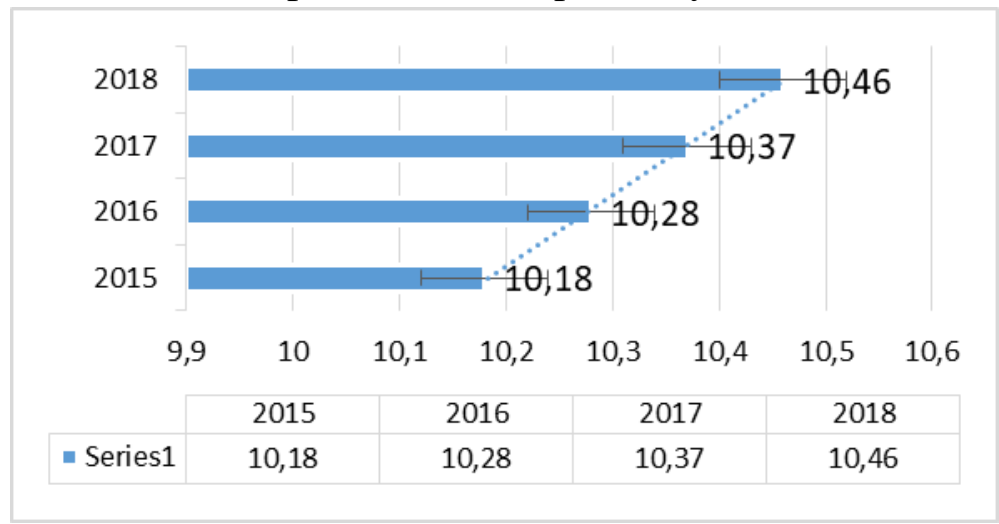

Source: DKI Jakarta Population Statistics Data, 2018

Moreover, the overview of the data on the development of the population of DKI Jakarta based on age from 2017-2018 is as follows:

Figure 2.Total Population of DKI Jakarta Based on Age

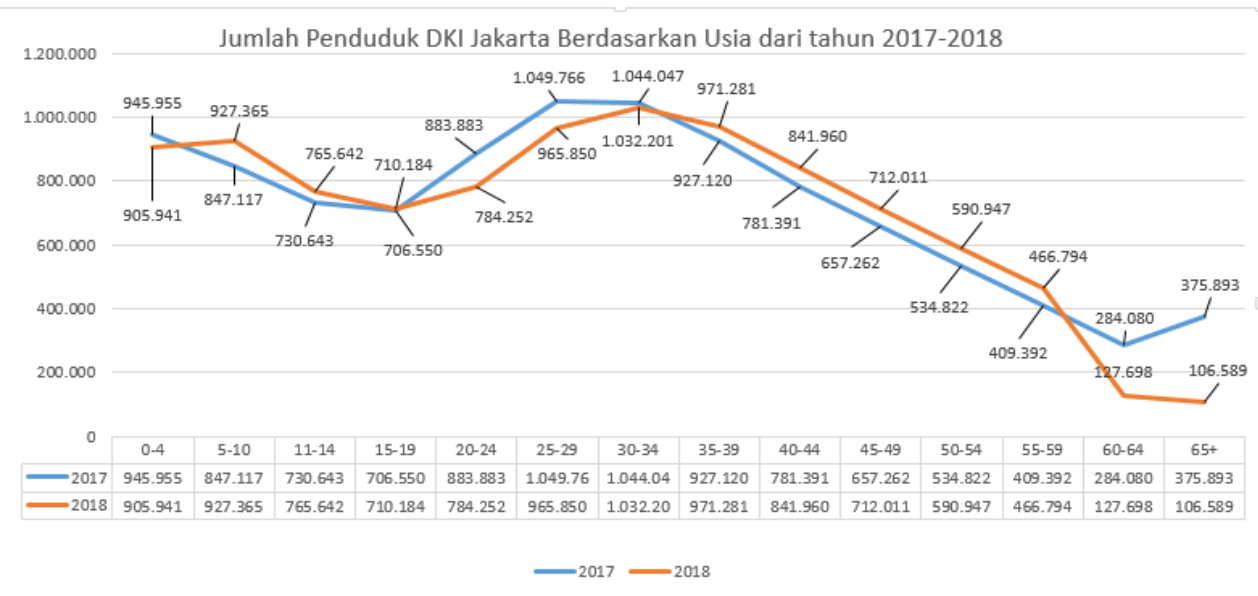

Source: DKI Jakarta Population Statistics Data, 2018 
The data show that the total population of Jakarta in 2017 was 10,177,924 people, while in 2018 it increased to $10,467,629$ people. For this reason, it can be concluded that every day the population in the capital city of Jakarta increases by 269 people, or 11 people per hour. With the condition of the population that is increasing from year to year, while the land does not increase, Jakarta is actually getting narrower with the management of housing which tends to be irregular, and therefore it automatically experiences "involution". As reviewed by Akung (2020) in the Kompas Daily, Tuesday, March 31, 2020, it shows that data on the poor population of Jakarta, spanning 2017-2019 (thousands of people), are; 2015 (368.67 / 3.61\%), 2016 (385.84 / 3.75\%), 2017 (393.13 / 3.78\%), 2018 (372.26 / $3.55 \%$ ), and in $2019(262.30 / 3.41 \%)$.

On the other hand, public awareness of the environment tends to be low. This means that in each area of administrative city, various cases are often found, for example, Watershed (DAS) and Green Open Space (RTH) as social facilities which previously received less attention from various parties. From aforementioned problems, this study discusses community problems, especially issues of environment management in Jakarta. Jakarta which has been known as the center of economy, bureaucratic politics, education and culture, as well as the center for the development of science and technology, seems to be the center of destination for urban migrants with various motives and backgrounds.

However, due to the uneven growth of the population with the geographic conditions, the condition of the population will be a problem, especially related to environment management. It is proven that "greedy" developers and the rampant of illegal settlements will result in the damaged and polluted environment. Public awareness of the environment tends to be low. Evidences of problems occurred in various areas, including Central Jakarta, North Jakarta, West Jakarta, East Jakarta and South Jakarta. However, in South Jakarta area, especially in Pesanggrahan, it turns out that there is still a protected forest area managed by Sangga Buana community with an ecological wisdom approach. The existence of an area of 40 hectares located in the Pesanggrahan River Watershed, Karang Tengah, Lebak Bulus, South Jakarta, at least gives South Jakarta residents a public area. The urgency of the protected forest area is very important, because in the midst of the 
siege of "concrete forest" and the high population, it turns out that there are still protected areas left to be enjoyed as public facilities.

Therefore, this study seeks to obtain answers and update research results. The research problem is how the efforts of the Sangga Buana farmer group in the urban environment management and development, as well as how the participation of community components which include; the general public, academics, non-governmental organizations, street youth, and related government agencies also support environmental management through a local cultural approach.

\section{Literature Review}

Related to the theme of the study, the theory that is relevant to be the foundation to this study is ecological theory. Ecology for humans can be defined as the study of the form and development of communities in a population where humans live and occupy a certain geographic location. Steiner (2002) stated that the scope of human ecology includes: (1) Set of connected stuff (a group of things that are interrelated); (2) Integrative traits (integrative characteristics); (3) Scaffolding of place and change. Furthermore, looking at current developments, Steiner said human ecology emphasizes the interrelated structure of life, which involves elements of humans, animals and plants and other social conditions that require wise and sustainable management.

The concept of scope means that it contains two meanings of consciousness, namely; awareness of the fundamental unity of the environment and awareness that there are differences in that unity. Awareness of the environment is not only about how to create something that is beautiful or clean, but also need to create obligations for human to respect the rights of others. The rights of other include enjoying and feeling the balance of nature in a pure manner, so that activities that are personal or group that lead to personal gain and have no tolerance should be avoided.

In theory, humans and the environment have a very strong correlation. Both mutually give and take, and have a big influence on each other. The influence of environment on humans is more passive, while the influence of humans on nature 
is more active (Gea, Panca, \& Wulandari, 2005). Humans have the ability to explore nature and environment, get a good character (Cahyono, et al., 2018; Oktarina, 2018; Wulandari, \& Kristiawan, 2017), Hence, they are able to change it to their wishes. Although nature has no active-exploratory desire and ability towards humans, slowly but surely, what happens to nature, directly or indirectly, will have an impact on human life. Learning from this theory, it needs to be used as analytical tools that the good and bad side of environment, humans have a responsibility to it.

\section{Methods}

The research was conducted in the area of the Sangga Buana Pesanggrahan farmer community, Karang Tengah Village, Lebak Bulus District, South Jakarta. Through a qualitative approach (Qualitative Research), it is hoped that it can step into the life of certain communities, both events, behavior, organizational functions, social movements (Koentjaraningrat, 1997) and Creswell (2010). In Danial (2009), and Sugiyono (2015) study, researchers investigated not only holding on to one particular theory, but as well as to other studies related to the field to be explored, interpretive, descriptive, and concluding.

Based on the research focus on ecology-based Civic Engagement, the selection of informants was a community leader who was also the pioneer of the formation of the Sangga Buana community. Furthermore, to complement and strengthen the data, it is strengthened by literature reviews, both in the form of books, e-books, journals, e-journals, articles, social media, and other supporting media such as photo documentation, maps, and other document sources.

\section{Results and Discussion}

\section{General Description of Sangga Buana Community}

Sangga Buana Community is volunteer on environment work and has a focus area on the Pesanggarahan River Watershed, precisely in Karangtengah Lebak Bulus, South Jakarta. The area of the Sangga Buana Community reaches 40 hectares. Geographically, the Pesanggarahan River Watershed covers the Depok 
area, South Jakarta, and South Tangerang. As an overview regarding the object of research, it can be seen through the following picture:

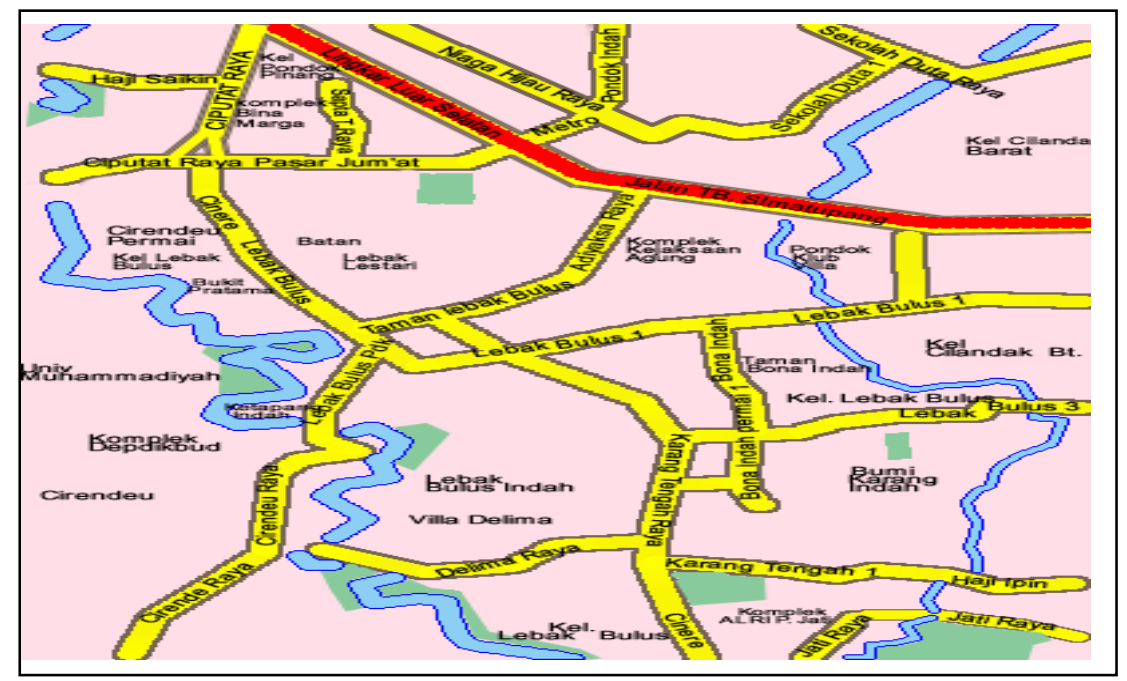

Figure 1. Map of Research Area,Central Karang, Lebak Bulus, South Jakarta Source: Map of Pesanggrahan Watershed Area, Central Karang, Lebak Bulus, South Jakarta (retrievedbyresearchers/ED-2020)

As stated by $\mathrm{H}$. Chaerudin as the pioneer of the establishment of the Sangga Buana community in the Pesanggrahan River area, in the 1950-1960s there were still many migrants who went fishing, remembering that at that time there were still various kinds of fish. However, over time, around 1976 the watershed (DAS) suffered very serious damage caused by its surrounding, for example, various types of garbage piled up, blackened river water and the establishment of slum houses along the riverbanks.

Along with the success of the Sangga Buana community, in the end not only was it enjoyed by local residents, butit also makes the area becoming a giant laboratory and is open to a number of groups, both universities, researchers, and guests from within and outside the country to conduct studies. As stated by $\mathrm{H}$. 
Chaerudin "currently the Sangga Buana Community which is centered in the Pesanggrahan watershed can be used as a center for environmental conservation". Through the hard work of the volunteers, the hope is for the government to understand that development is not always profit-oriented, but development policies that are in harmony with nature should be taken into account. The Sangga Buana Community has tried and received support from various parties. The goal is to try to educate people not to be smart, but to understand. This means that if the community understands their environment, they can put it into practice.

As stated by $\mathrm{H}$. Chaerudin, education can be carried out through a selftaught process, meaning that there is no need to use seminars as formality. For this reason, the Sangga Buana Community deliberately provides plant and fish seeds to carry out planting and conserving fish movements. Visitors can buy plants and broodfish in the Sangga Buana Community, for planting and stocking in Pesanggrahan River. That is the real practice for people who understand the environment. "The following is the activity of the Sangga Buana community with various volunteers doing the exploration of the Pesanggarahan watershed.

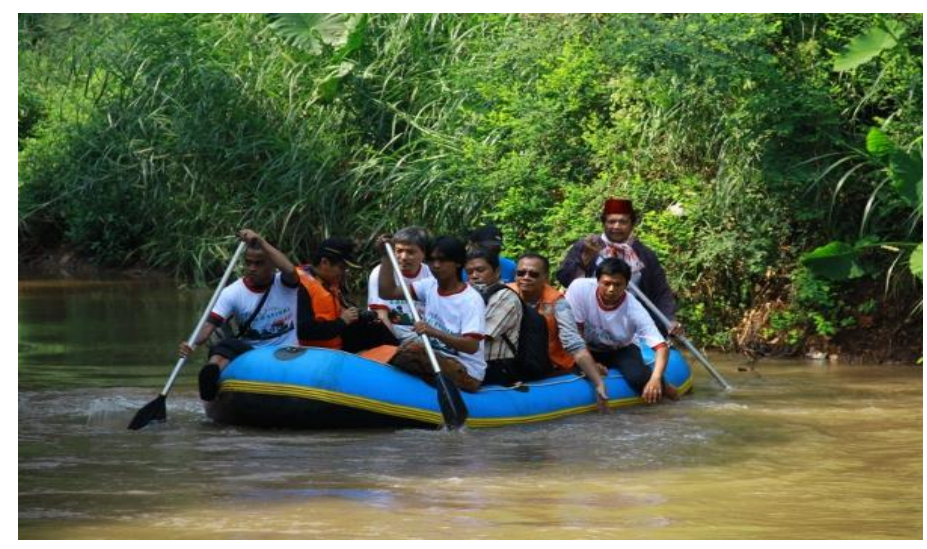

Figure 2. Watershed exploration activity by Sangga Buana community with environment volunteer

Source: Sangga Buana community profile (retrieved by researchers-ED-2020) 
Therefore it must be admitted that when talking about protected forest areas, then the services of the farmers who joined the Sangga Buana community as the pioneers of the area should not be forgotten. Through direct observation in the hands of the farming community led by $\mathrm{H}$. Chaerudin, the existence of a protected forest has been initiated and preserved until now.

Realizing that the movement carried out by $\mathrm{H}$. Chaerudin was considered positive and beneficial to the community and its surroundings, this movement finally received support from various institutions, both from; the local community, the academic community (universities, colleges, academies), non-governmental organizations (NGOs), the Ministry of Social Affairs, and other related institutions, especially local governments).

The existence of the Sangga Buana farmer group is inseparable from the Betawi social and community system whose people arenativeto the area and have local wisdom values, thus helping to realize this protected forest area. The character of the manager who respects differences, brought 17 people who were the first to do environmental conservation together, resulting in good management. On this basis, it is necessary to conduct an in-depth study related to urban environmental management efforts through a cultural approach to ecological and cultural wisdom by involving the participation of the surrounding community.

\section{Sangga Buana Community Principles as Environment Volunteer}

After receiving support from various elements, both government and corporate CSR, such as; HSBC, Green Radio, Institutions for Basic Education to Higher Education, the Sangga Buana Community are among the volunteer communities that contribute in reducing environmental pollution problems and are able to help maintain ecological wisdom as a medium for community learning. This is because the results of the previous study, as released by the Green Transformation Program Manager, Hendra Michael Aquan, Saturday, June 25, 2011. Research on water quality in Pesanggrahan River was conducted at two points, namely Srengseng City Forest, Kembangan, West Jakarta, and SanggaBuanaCinere, South Jakarta by using three parameters. First, there are 
biological parameters by looking at the living aquatic biota, namely crabs, snails and shellfish. Second, there are chemical parameters by looking at the level of ammonia nitrate, detergent, $\mathrm{PH}$ (acidity), and oxygen in the water. Third, it was done by looking at the metal content in river sediments. The results of the study concluded that the river water in Pesanggrahan River was confirmed to have been contaminated by chemicals and metals to a moderate level.

The results of this study recommend that the water conditions of the river before being managed by the Sangga Buana community were quite dirty with low oxygen levels, which was only $3.2 \%$ from the normal level of $6 \%$. There were only two findings of biota that survive in the river, namely snails and worms. In addition, three types of heavy metals were also found, namely lead, mercury and hexavalent chromium.

The results of the study also show that the water quality condition in Pesanggrahan River has been degraded and are not in accordance with the Regulation of the Governor of DKI Jakarta Number 582 of 1995 concerning the Allocation of River Quality Standards. This regulation is an instrument to maintain the quality of river water from being polluted.

The results of this study have been confirmed by laboratory research at the National University of Jakarta and the Laboratory of the Jakarta Environmental Management Agency (BPLHD). Furthermore, the results of the research were submitted to the Provincial Government of DKI Jakarta on Saturday, June 25, 2011, as a recommendation to save water quality and the environment in the Pesanggrahan River area.

To support this study, based on the opinion of a Betawi historian and cultural observer (Ridwan Saidi), the Pesanggrahan River actually began to experience damage since the VOC (a Dutch trading company) came to the country and became rulers, namely in the 19th century. VOC officials cut logs along the Pesanggrahan River. This destruction lasted until the 20th century, when officials and government officials committed corruption acts.

Forest destruction that contains wood species for harvesting and selling. However, the sale and the results were not reported to the Dutch Government. 
"Bayur wood is a very good type for house building. Colonials cutand sold them on the black market or what is now called as illegal logging," Ridwansaid.

As a result of this deforestation, the Pesanggrahan River experienced the impact, namely, the river became shallow and narrowed. In addition, other impacts were also caused, such as frequent flooding. It has been proven since then that the Pesanggrahan River was no longer used as a transportation route, because apart to silting, the color of the water became cloudy.

As stated by $\mathrm{H}$. Chaerudin "in the late 1980s the Pesanggrahan river generally became dirty and had a black color. Various types of garbage were scattered in the river, causing an unpleasant odor. Then there was silting that often caused flooding. On the banks of the river, the remaining trees were cut down".

Chaerudin divided the Pesanggarahan area into five points; the first place is in the Karang Tengah area, Lebak Bulus, which he named point one. In that place, the working area to conserve nature is 120 hectares. An area of 40 hectares goes to the South Jakarta area, while the rest goes to the Depok and South Tangerang areas.

For the point two, it covers the Pesanggrahan River flow area which crosses the Cinangka area, Depok. The third point covers the Pasir Putih area, Bogor. The fourth point covers the Cilebut area, Bogor. Finally, the fifth point is the entry point to the upstream area of the Pesanggrahan River, which includes seven sub-districts in Bogor; among them are Mount Bunder, Cikampak, Cimande, and Cidahu. At each of these points, by making an approach to environmental volunteers, Chaerudin recruited young people and people who wanted to save the environment. He gave them understanding to actively save the environment. Chaerudin hopes that the social work area of the Sangga Buana community is not only the area that has been mentioned, but still hopes that it will expand to the downstream area of Jakarta.

\section{The Contribution of Sangga Buana Community on Environmental Control}

The Sangga Buana Community cannot fully solve the environmental problems in the Pesanggrahan Watershed. However, it has been acknowledged by various elements of society, especially the DKI Jakarta Government. According to 
the Head of Conservation and Environmental Management of the DKI Jakarta Regional Environmental Management Agency (BPLHD) at that time, Rusman E. Sagala, after management and control had been carried out, in general the condition of the water and the Pesanggrahan watershed was better than other rivers in Jakarta.

Because overall, the DKI Jakarta area is traversed by 13 rivers, and the condition of the Pesanggrahan River is relatively better. Based on the results of monitoring by the DKI Jakarta Government, since 2009 on average the Pesanggrahan River has had the status of a river that has a moderate level of pollution (moderate pollution). Furthermore, in 2010 to 2020, the Pesanggrahan River had been the only river that has a status with a light level of pollution (light pollution) compared to other rivers in DKI Jakarta.

The DKI Jakarta government acknowledged this quality improvement on the initiative of Chaerudin and the Sangga Buana Community in collaboration with various parties. The efforts that have been made by the Sangga Buana Community are at least able to minimize the pollution that occurs in the Pesanggrahan River. For this reason, the DKI Jakarta Government always supports the efforts made by the community in collaboration with various parties, such as CSR companies, educational institutions, and non-governmental organizations that are committed in protecting ecological wisdom.

Currently, the Pesanggrahan Riverbanks, which are set up as a public space in the form of parks and plantations, are crowded with visitors from all over Jakarta and outside Jakarta. This is because the park has been successfully transformed into a protected forest and has become an alternative ecological tourism object for the people of DKI Jakarta and its surroundings with no charge. The following is an overview of the beauty of the public space of the Sangga Buana community. 


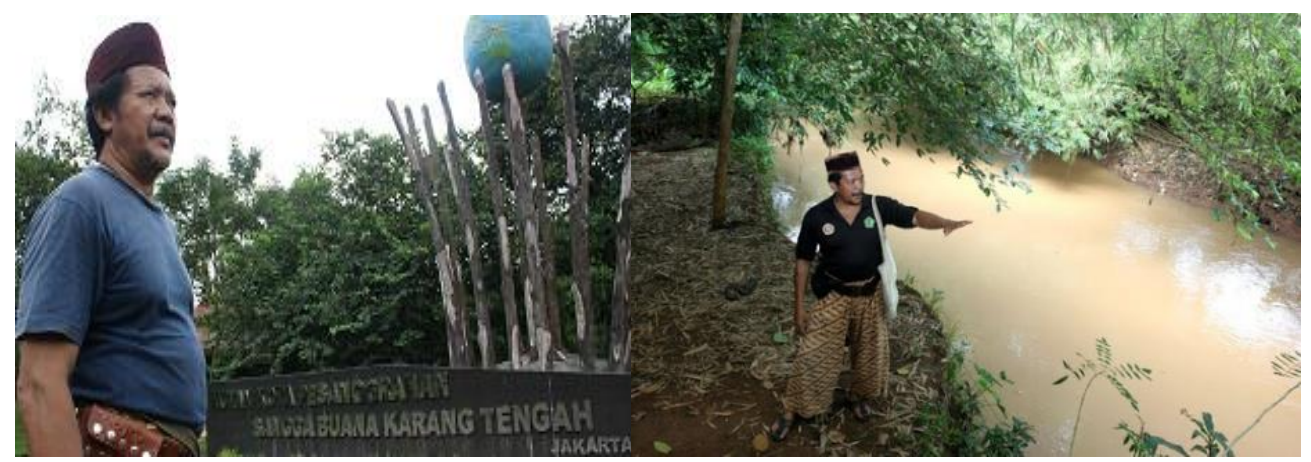

Figure 3. The Condition of Sangga Buana Park Area and Pesanggrahan River with the Pioneer (H. Chaerudin)

Source: Sangga Buana Community Profile (retrieved by researchers-ED-2020)

Among the interesting programs, the visitors were invited to plant various types of trees and releasebroodfish at the river. Visitors are also not prohibited from fishing or taking protected forest products such as picking young leaves for vegetables and cutting bamboo shoots (young bamboo), but they must still be undersupervision and consentof the farming community. However, there is a prohibition as stated by $\mathrm{H}$. Chaerudin, namely that visitors must not catch the fish by poisoning or other cruel methods, because it will cause environmental damage and kill various types of fish which it means they do not consider ecological wisdom anymore. Visitors can also buy various types of vegetables and livestock products from farmers who need management funds, such as fruit crops, fish, goats, cows, horses, and various other singles.

\section{Partnership Collaboration with Educational Institutions}

As the results of the researchers' observations at the research location, there are supporting facilities for the implementation of social and community education. Several public facilities that have been initiated and produced by the Sangga Buana community include; development of the Pesanggrahan River watershed into a park equipped with a discussion room and a simple library, plantations with various types of protected plants, medicines, and furniture plants 
(bamboo), various types of fruit plants, ponds for fish farming, various types of poultry such as; chickens, ducks, goats, cows, to horses. Among the farming activities of the Sangga Buana Community, the following picture is shown:

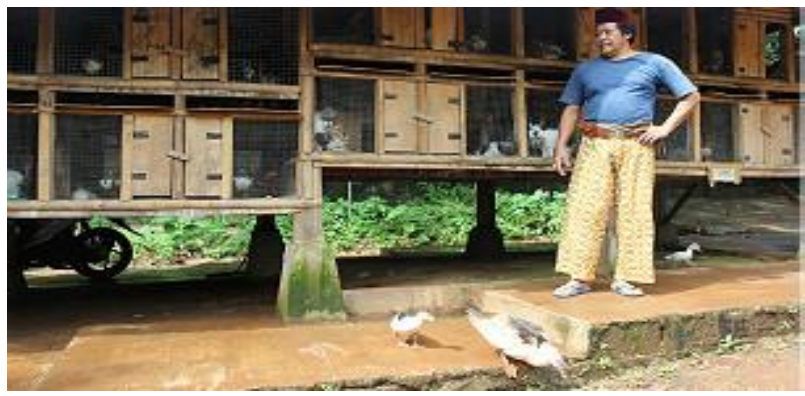

Figure 4.The Pioneer of Sangga Buana Community with Various Farming Objects Source: Picture ED-2019 and Sangga Buana Community Profile 2019

Other public facilities that have been managed by the Sangga Buana community are in the form of an open field as a meeting area and cultural stage, fishing area, swimming pool, providing lodging facilities equipped with a restaurant, futsal hall and many other sports.

Therefore, visitors from various educational institutions, from primary, secondary, to higher education also learn and contribute their knowledge to the Sangga Buana Community. Thus the Sangga Buana Community with the public facilities it manages can be used as a social education laboratory. Several expatriate groups from Germany, England, France, Australia, Netherlands, and Japan also tried to experience the beauty of this area. To accompany these foreign tourists, the Sangga Buana Community received assistance of tour guides from Trisakti University who were previously given the knowledge about nature and history. It is recorded that around 4000 people come to visit each year. 


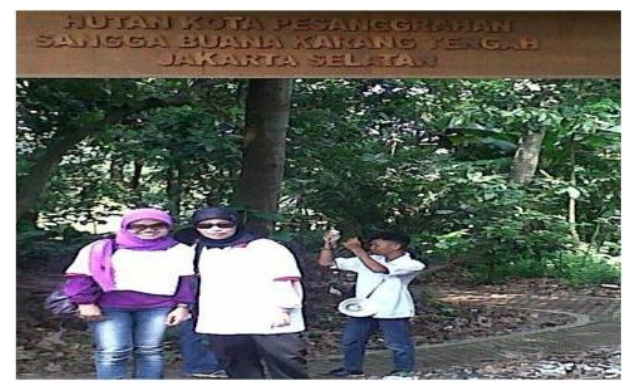

Figure 5. Community visit to the Sangga Buana Community as an environmental tourism Object

Source: Picture ED-2019 and Sangga Buana Community Profile 2019

Based on the information from the pioneer of Sangga Buana Community (H. Chaerudin), it has received a lot of support and appreciation for ecological management so far, even though the Sangga Buana Community actually did not expect it. However, for all parties, it is still appreciated for the collaborative efforts so far, both from the government, private institutions, and educational institutions.

Various institutions that have collaborated with the Sangga Buana Community so far are primary, secondary and higher education institutions. Especially for higher education institutions that have been Sangga Buana's partner is University of Indonesia, Jakarta State University, Trisakti University, Prof. Muhammadiyah University. DR. HAMKA, as well as other universities. This partnership collaboration is generally a form of higher education institutions in implementing the process of education, research, and community empowerment. Thus, it is hoped that it can mutually benefit and contribute. It means that people through the community and students can learn directly from the realities of people life.

\section{Conclusion}

From the study above, it can be concluded that it cannot be denied that the environment in Jakarta and its surroundings has indeed been polluted and contaminated. However, the community and all related parties should be grateful 
that the South Jakarta area, especially in the Pesanggrahan River watershed, there are still communities that are willing to devote themselves as volunteers to manage and maintain the value of ecological and cultural wisdom, so that it can give meaning to all parties. These meanings include economy, education, tourism, religion, and environmental health.

The suggestion to all parties what must be done in order to interpret the importance of resilience to ecological wisdom, namely: For the general public, a movement to build awareness through an ecological and cultural wisdom approach is required. It is necessary to be extra careful with all activities that can cause environmental pollution such as disposing of garbage and building residences without permits in the vicinity of a watershed (DAS), because it will be detrimental to all parties. For the Regional Government, it is necessary to provide full support for environmental volunteer activities, because environment volunteers have contributed in maintaining and overcoming social problems in the community, especially issues of ecological awareness. For the Sangga Buana community, it is necessary to carry out strategies and innovations in an effort to carry out social programs by collaborating with various elements. For education field, both primary, secondary and higher education, it is necessary to make the Sangga Buana Community an area of educational and scientific development, because the level of success of education is not only carried out in theory or in formal institutions. However, it is necessary to learn from real life, so that science can contribute in practice.

\section{Acknowledgement}

The authors wish to thank to participant, the leader and Sangga Buana community were support for this research. Acknowledgments were also extended to all who contributed to this research. Thank you also expressed to all participants for their contribution in helping collect data and in testing research book products. Thank for the team JMKSP (Jurnal Manajemen, Kepemimpinan, dan Supervisi Pendidikan) that given suggestion in peer review process. 


\section{References}

Akung, M. A. (2006). Discussing Our Ecological Wisdom. Jakarta: Compass. November 30, 2006

Bearss, K., Johnson, C., Smith, T., Lecavalier, L., Swiezy, N., Aman, M., \& Scahill, L. (2015). Effect of parent training vs parent education on behavioral problems in children with autism spectrum disorder: a randomized clinical trial. Jama, 313(15), 1524-1533.

Cahyono, H., Suhono, S., \& Khumairo, A. (2018). Pendidikan Karakter Bagi Pelaku Pedofilia (sebuah Strategi dalam Mengatasi Amoral) [Character Education for Perpetrators of Pedophilia (a Strategy in Overcoming Immorality)]. JMKSP (Jurnal Manajemen, Kepemimpinan, dan Supervisi Pendidikan), 3(1), 1-19

Cresswell, J. W. (2010). Research Design: Qualitative, Quantitative, and Mixed Approaches (third edition). Yogjakarta:Student Library

Danial, E. (2009). Method of Writing Scientific Papers. Bandung: Citizenship Education Laboratory,University of Education

Dudley, R. L., \& Gitelson, A.R. (2003). Civic Education, Civic Engagement, and Youth Civic Development. PS: Political Science and Politics, 36(2), 263267.

Dunn, A. W. (2004). Community Civics and Rural Life (Digitized Version). Boston-New York-Chicago: DCHeath \& Co., Publishers.

Fauzi, D. R., \& Bestari, P. (2019). The Role of Youth Organizations as a Political Education Means in Improving Youth Political Participation in 2018 Regional Election in Bandung City. JIPIS (Journal of Educational Sciences and Social Sciences), 28(1), 39-46.

Gea, AA, Panca, A., \& Wulandari, Y. (2005). Relationships with the Natural World, Science and Technology, and Work. Jakarta: Gramedia.

Koentjaraningrat. (1997). Community Research Methods. Jakarta: PT. Gramedia

Keraf, U. S. A. (2002). Environmental Ethics. Jakarta: KompasBook Publishers 
Mandasari, M., Rahmayanti, F., Derbi, H., \& Wimardhani, Y. S. (2021). Special Care Dentistry Perception among Dentists in Jakarta: An Online Survey Study. PloS one, 16(4), e0249727.

Oktarina, R. (2018). Implementasi Kurikulum 2013 Dan Pendidikan Karakter [Implementation of 2013 Curriculum and Character Education]. JMKSP (Jurnal Manajemen, Kepemimpinan, dan Supervisi Pendidikan), 3(2), 270279.

Putri, R. F., Wibirama, S., \& Giyarsih, S. R. (2018, April). Population condition analysis of Jakarta land deformation area. In IOP Conference Series: Earth and Environmental Science (Vol. 148, No. 1, p. 02007). IOP Publishing.

Sidabutar, T., \& Srimariana, E. S. (2020). The Connectivity of Nutrient Ratios on The Abundance of Phytoplankton Population In Jakarta Bay. In E3S Web of Conferences (Vol. 147, p. 02012). EDP Sciences.

Tidball, KG, \& Krasny, ME (2010). Urban environmental education from a social-ecological perspective: Conceptual framework for civic ecology education. Cities and the Environment (CATE), 3(1), 11.

Walsh, E., Hooven, C., \& Kronick, B. (2013). School-wide staff and faculty training in suicide risk awareness: Successes and challenges. Journal of Child and Adolescent Psychiatric Nursing, 26(1), 53-61.

Wulandari, Y., \& Kristiawan, M. (2017). Strategi Sekolah Dalam Penguatan Pendidikan Karakter Bagi Siswa dengan Memaksimalkan Peran Orang Tua [School Strategies in Strengthening Character Education for Students by Maximizing the Role of Parents]. JMKSP (Jurnal Manajemen, Kepemimpinan, dan Supervisi Pendidikan), 2(2), 290-302.

Krasny, M. E., Russ, A., Tidball, K. G., \& Elmqvist, T. (2014). Civic Ecology Practices: Participatory Approaches to Generating and Measuring Ecosystem Services in Cities. Ecosystem services, 7, 177-186.

Krasny, ME, Kalbacker, L., Stedman, RC, \& Russ, A. (2015). Measuring Social Capital Among Youth: Applications in Environmental Education. Environmental education research, 21(1), 1-23.

Lukito, YN (2018). The Urban Forest Project as an Extension of Landscape Immersion and a Way To Support Community Engagement in the 
Ragunan Zoo, Jakarta. ASEAN Journal of Community Engagement, 2(2), 2.

Steiner, F. (2002). Human Ecology, Following Nature's Lead. WashingtonCovelo-London: Island Press.

Sugiyono. (2015). Combination Research Methods (Mix Methods). Bandung: Alfabeta 